\title{
Estimation of groundwater recharge using GIS-based WetSpass model for Birki watershed, the eastern zone of Tigray, Northern Ethiopia
}

\author{
Esayas Meresa ${ }^{1} \oplus \cdot$ Gebeyehu Taye $^{2}$
}

Received: 18 July 2017 / Accepted: 14 September 2018 / Published online: 19 September 2018

(c) The Author(s) 2018

\begin{abstract}
This research aimed to use WetSpass model to estimate long-term average annual and seasonal groundwater recharge for Birki watershed $\left(45 \mathrm{~km}^{2}\right)$ in northern Ethiopia using long-term (10 years) hydro-meteorological and biophysical (soil, land use, topography, slope and groundwater depth) data of the watershed. Both primary and secondary input data were collected using field survey and disk-based data collection methods. The model was used to understand the groundwater recharge potential of the given area for wise utilization, proper management and future planning of the water resource. The results showed that, summer (rainy season) recharge ranges from 0 to $41.09 \mathrm{~mm} / \mathrm{year}$ with mean value of $24.1 \mathrm{~mm} / \mathrm{year}(96.5 \%)$, winter (dry season) recharge ranges from 0 to $1.9 \mathrm{~mm} /$ year with mean value of $0.8 \mathrm{~mm} /$ year (3.5\%) and yearly recharge ranges from 0 to $42.6 \mathrm{~mm} /$ year with mean value of $24.9 \mathrm{~mm} /$ year. Ten years of mean annual precipitation $573 \mathrm{~mm}$ contributed to $7.4 \%$ as recharge to the groundwater, $7.1 \%$ of surface runoff and $85.5 \%$ lost as evapotranspiration. Annually, 1.1205 million $\mathrm{m}^{3}$ water recharges into the groundwater table as recharge from the precipitation for the entire watershed area. Annually on average $0.17 \mathrm{~m}^{3} / \mathrm{d} / \mathrm{ha}$ groundwater can be extracted safely without depleting the groundwater. Understanding the groundwater recharge of the Birki watershed is important for management, proper utilization and future planning of water resources for sustainable management. It is also good baseline information for water resource experts and policymakers of the region for further investigation of water resources, design, and developmental activities and for planning purpose.
\end{abstract}

Keywords WetSpass model $\cdot$ Groundwater recharge $\cdot$ Birki watershed $\cdot$ GIS $\cdot$ Seasonal basis

\section{Introduction}

\section{Background and justification}

Water resource, which is the backbone and crucial element of life, is needed in sufficient quantity and quality to meet the increasing demand for domestic, agricultural and industrial processing operations (Fenta et al. 2014; Shanableh and Merabtene 2015; Arefayne et al. 2015). But, its availability is limited because of its natural distribution on the earth surface, in which $97.5 \%$ of the global water is saline existing in the oceans and only $2.5 \%$ is considered to be available for

Esayas Meresa

esayasmeresa@gmail.com

$1 \quad$ GIS and Agro-Meteorology Research Team, Mekelle Agricultural Research Center, Tigray Agricultural Research Institute, Mekelle, Tigray, Ethiopia

2 Department of LArMEP, Mekelle University, Mekelle, Tigray, Ethiopia biological use, i.e., fresh water. About $68.7 \%$ of the remaining $2.5 \%$ that is fresh water is locked up in glaciers while $30.1 \%$ and $0.9 \%$ represent groundwater, surface water, and other fresh waters, respectively (Shiklomanov 1998). It is a scarce, crucial and multifunctional natural resource found on the planet and the demand for fresh water is increasing worldwide as a result of urbanization, economic and population growth (Karimi and Bastiaanssen 2015). Because of its scarcity, proper planning and management of such resource in terms of distribution, management, utilization, and environmental functions are crucial for optimizing the resource use sustainably (Karimi and Bastiaanssen 2015).

Access to safe drinking water becomes a problem in many regions of the world particularly in dryland of developing countries because of high growing and competing demand of the resource. Urbanization and population growth in urban areas are not only stressing the capacity and sustainability of the existing water supplies but also it placing the supply at a greater risk of contamination. Moreover, humans are also affecting the global 
water resources through climate change by increasing atmospheric concentrations of greenhouse gases and aerosols, changes in land use land cover due to deforestation, industrialization, and urbanization will continue to affect the earth's climate by changing the temporal and spatial distribution of rainfall, temperature, evapotranspiration in particular and the whole hydrologic cycle in general (Sykes 2006).

Mostly, water resource is found as surface water and groundwater forms, surface water is not a reliable source as it is prone to seasonal fluctuations and susceptible to contamination through anthropogenic activities such as point, non-point pollution sources and biological pollutions (Fenta et al. 2014). However, groundwater is more suitable in quantity, readily available and is naturally protected from direct contamination by surface anthropogenic activities (Fenta et al. 2014). It is the largest reservoir of liquid freshwater on the planet and is critical for sustaining life on earth, as it is used to satisfy different human and environmental needs (Zomlot et al. 2015a).

Ethiopia is also endowed with a substantial amount of water resources. The country is divided into 12 river basins; 9 of which are wet river basins; 1 lake basin; and remaining 3 are dry river basins, with no or insignificant flow out of the drainage system. Almost all of the basins radiate from the central plateau of the country that separates into two due to the Rift Valley. Basins drained by rivers originating from the mountains west of the Rift Valley flow toward the west into the Nile River basin system, and those originating from the Eastern Highlands flow toward the east into the Republic of Somalia. Rivers draining in the Rift Valley originate from the adjoining highlands and flow north and south of the uplift in the center of the Ethiopian Rift Valley (Melesse et al. 2013).

There is surface water resource in Birki watershed and the community uses for different domestic and agricultural activities but there is no any information on the amount of groundwater recharge on the specific watershed for wise and sustainable utilization and proper management of the limited water resources. Thus, estimation of groundwater recharge in that specific watershed has its own role in solving the problems related to the management and planning of water resources for sustainable development using hydrological models such as WetSpass model with the help of GIS and remote -sensing techniques.

WetSpass model is a spatially distributed simulation model for water and energy transfer between soil, plants, and atmosphere under quasi-steady state. It predicts spatial patterns of surface runoff, evapotranspiration, and groundwater recharge on a regional scale (Batelaan and De Smedt 2007). The model understands a region as a regular pattern of raster cells. Every raster cell is further sub-divided into a vegetated, bare soil, open water, and impervious materials and seasonal water balance components are calculated for each grid cell.

The WetSpass model was applied in different authors, according to those authors, this model was implemented for groundwater recharge estimation and it simulates with a good and accepted result, which is the main objective of this research work. Therefore, this research study aimed to implement the newly emerged tools of geographic information system/science (GIS)-based WetSpass model for estimation of groundwater recharge for Birki watershed $\left(45 \mathrm{~km}^{2}\right)$, Northern Ethiopia.

\section{Materials and methods}

\section{Description of study area}

\section{Geographical location of Birki watershed}

The study area, which is Birki watershed, is located in the Geba River Basin of Eastern Regional State of Tigray, Northern Ethiopia (Fig. 1). The watershed is found within two districts, i.e., Kilte awelaelo and Atsebi-Wenberta. Geographically, it is located in latitudes of $13.65^{\circ}-13.75^{\circ}$ Northing and longitudes of $39.60^{\circ}-39.71^{\circ}$ Easting with elevation ranging from 1999 to $2514 \mathrm{~m}$ above mean sea level with an area of $45 \mathrm{~km}^{2}$ (own processing). The watershed receives mean annual rainfall of $573 \mathrm{~mm}$. The Birki River flows from the eastern escarpment of the Eastern Zone of Tigray to the west contributing the flow to Geba River a tributary of Tekeze River. It is a perennial river but flows are extremely low in the dry season and high floods during the wet season (July to September).

\section{Research methodology}

The WetSpass model was used as a methodology to simulate temporal average and spatial differences of surface runoff, actual evapotranspiration, and groundwater recharge in seasonal and annual basis for Birki watershed. Generally, to run the WetSpass model, two basic input parameters, which are hydro-meteorological and biophysical data related to the watershed are needed and the necessary data should be prepared in the required grid and database file (DBF) formats.

\section{Basic concepts of WetSpass model}

WetSpass is an acronym which stands for water and energy transfer between soil, plants, and atmosphere under quasisteady state (Batelaan and DeSmedt 2001; Batelaan and De Smedt 2007). It uses both physical and hydro-meteorological input files for simulation of the long-term average spatial patterns of surface runoff, actual evapotranspiration and 


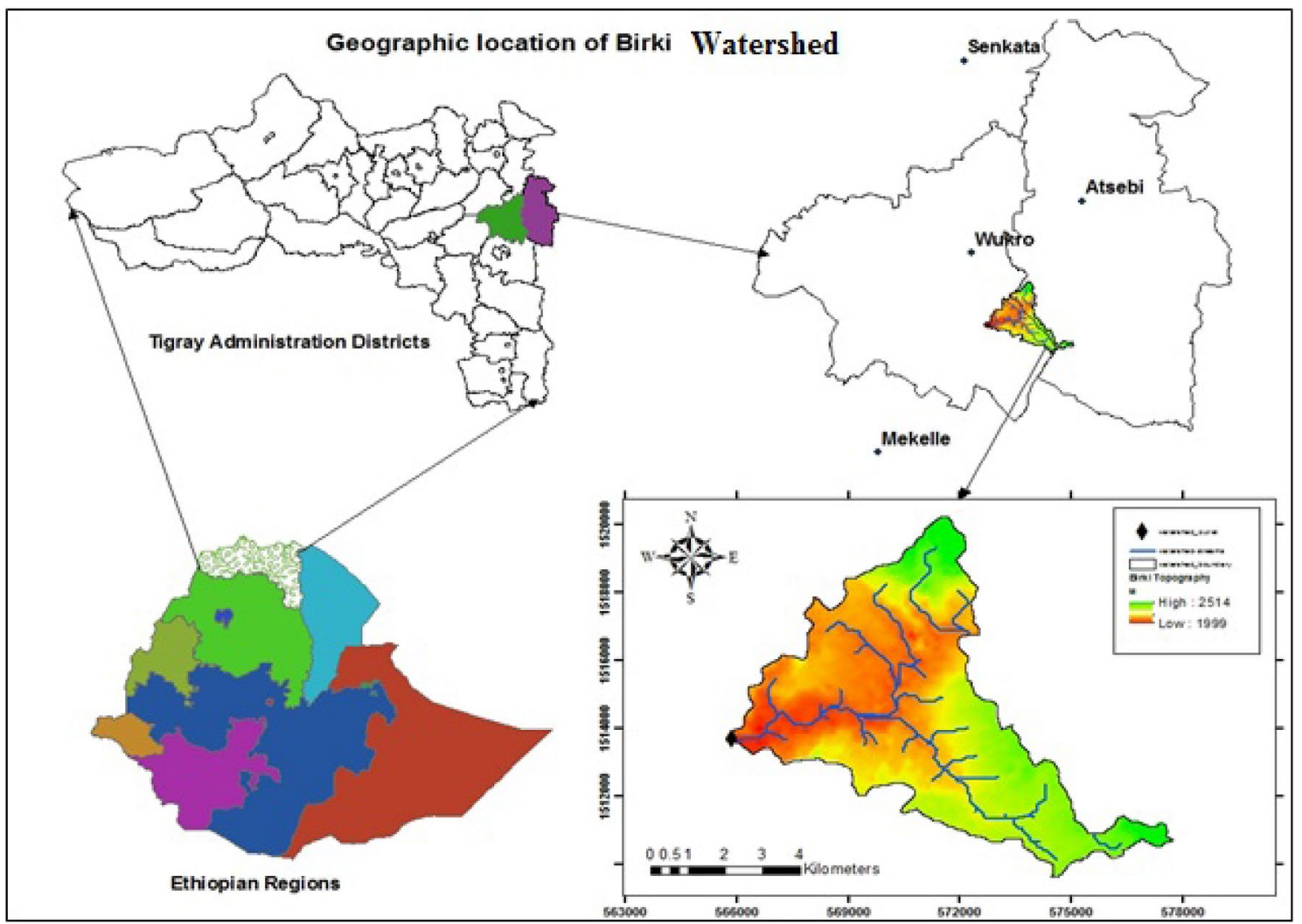

Fig. 1 Map of the area under investigation. Birki watershed: Northern Ethiopia. (Source: Own processing)

groundwater recharge which is suitable for studying longterm effects of land-use changes on the water regime in a watershed region (Batelaan and DeSmedt 2001, 2007; Aish et al. 2010). The application of this model is compatible and integrated with GIS ArcView software during the simulation process. It estimates the spatial difference of groundwater recharge at the seasonal and annual basis and it was successfully applied in different countries by different authors, as a result, the findings of those authors showed that groundwater recharge estimation was successfully estimated with a good result (Al Kuisi and El-Naqa 2013).

\section{Model description}

The total water balance for a given raster cell (Fig. 2) is split into independent water balance components for the vegetated, bare-soil, open-water and impervious parts of each cell. This allows one to account for the non-uniformity of the land-use per cell, which is dependent on the resolution of the raster cell. The processes in each part of a cell were set in a cascading way. This means that an order of occurrence of the processes, after the precipitation event, is assumed. Defining such an order is a prerequisite for the seasonal timescale with which the processes will be quantified. The quantity determined for each process is consequently limited by a

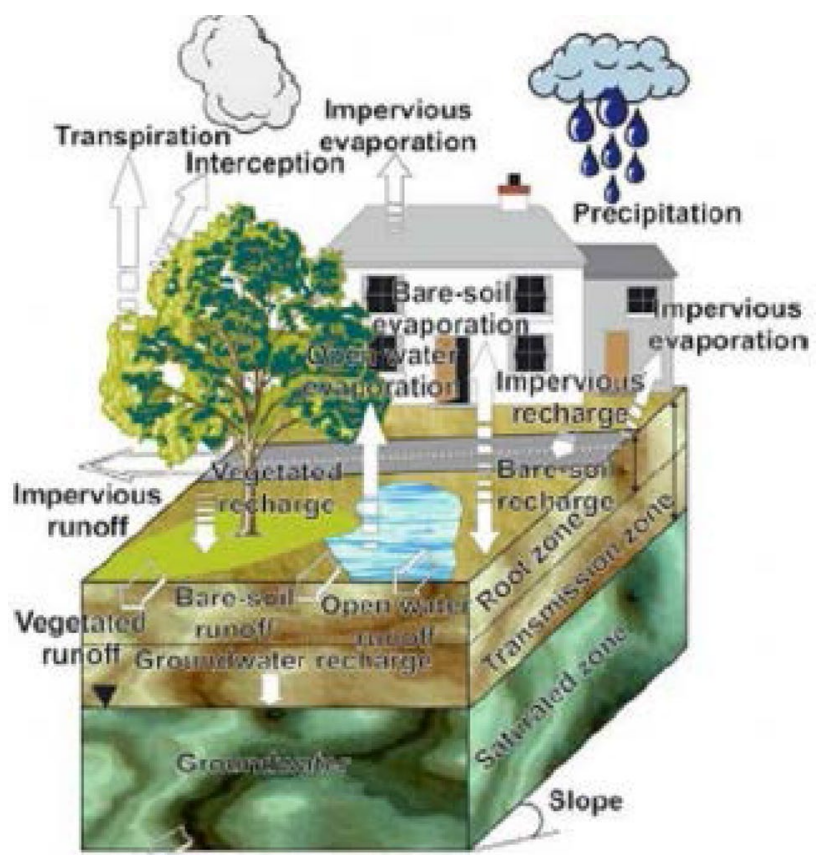

Fig. 2 Graphical iterative representation of water balance calculation of a hypothetical raster cell showing surface and sub-surface processes, after Batelaan and De Smedt (2001) 
number of physical and hydro-meteorological constraints of the given area under investigation (Batelaan and DeSmedt 2001).

\section{Water balance calculation using WetSpass model}

Water balance components of vegetated, bare-soil, openwater and impervious surfaces are used to calculate the total water balance of a raster cell using the Eqs. (1)-(3).

$$
\begin{aligned}
& \mathrm{ET}_{\text {raster }}=a_{\mathrm{v}} \mathrm{ET}_{\mathrm{v}}+a_{\mathrm{s}} E_{\mathrm{s}}+a_{\mathrm{o}} E_{\mathrm{o}}+a_{\mathrm{i}} E_{\mathrm{i}} \\
& S_{\text {raster }}=a_{\mathrm{v}} S_{\mathrm{v}}+a_{\mathrm{s}} S_{\mathrm{s}}+a_{\mathrm{o}} S_{\mathrm{o}}+a_{\mathrm{i}} S_{\mathrm{i}} \\
& R_{\text {raster }}=a_{\mathrm{v}} R_{\mathrm{v}}+a_{\mathrm{s}} R_{\mathrm{s}}+a_{\mathrm{o}} R_{\mathrm{o}}+a_{\mathrm{i}} R_{\mathrm{i}}
\end{aligned}
$$

where $\mathrm{ET}_{\text {raster }}, S_{\text {raster }}, R_{\text {raster }}$ are the total evapotranspiration, surface runoff, and groundwater recharge of a raster cell, respectively, each having a vegetated, bare-soil, open-water and impervious area component denoted by $a_{\mathrm{v}}, a_{\mathrm{s}}, a_{\mathrm{o}}$, and $a_{\mathrm{i}}$, respectively. Precipitation is taken as the starting point for the computation of the water balance of each of the abovementioned components of a raster cell, the rest of the processes, such as interception, surface runoff, evapotranspiration, and recharge follow in an orderly manner.

\section{WetSpass model data inputs preparation and their sources}

GIS-based hydrological models such as WetSpass model was used for analyzing groundwater systems in steady-state condition and needs long-term average hydro-meteorological data and spatial patterns of watershed-based biophysical layers as the main inputs. WetSpass needs the parameters in seasonal basis, as a result, four months of June, July, August, and September are considered as summer (main rainy season) and the remaining 8 months are considered as winter (dry season) in the case of Ethiopian condition particularly at the study area. Grid maps and parameter tables are required as inputs for the model and were prepared with the help of ArcGIS tools and Erdas Imagine software. These grid maps were a land-use land cover, soil texture, slope, topography and groundwater levels, precipitation, potential evapotranspiration and wind speed. The input files prepared as parameter tables were also prepared in a database file format (dbf); these are summer and winter land use land cover, soil texture and runoff coefficient. All the inputs and their sources were mentioned as follows in Table 1.

\section{Biophysical input data and hydro-meteorological grid maps preparation}

Land use land cover map of the watershed was prepared using a supervised image classification method with an overall accuracy of $82 \%$ and Kappa statistics of 0.78 using Erdas Imagine. The interpolation technique used here is an inverse distance weighted (IDW) method and it is used for estimating missing values between known measurements. Hydro-meteorological and soil textural map of the watershed was also prepared using inverse distance-weighted (IDW) interpolation technique. Around 65 soil samples were taken from the watershed with soil depth of $0-15 \mathrm{~cm}$ and with a distance of $100 \mathrm{~m}$ among the different land use types in the dry season and taken in to the laboratory to identify their textural classes, meteorological data were collected from the National Meteorological Agency(NMA), PET was calculated using Cropwat- 8 software and groundwater depth were collected from the regional water resources office and it was prepared by subtracting static water level from the surface elevation of the boreholes and springs found within the watershed. All these parameters were prepared for the year 2015 as spatial data. The reason for using this interpolation

\begin{tabular}{|c|c|c|c|}
\hline ID & Input parameter & Sources & Processing resolution \\
\hline 1 & Soil texture & Map based on soil sample analysis & $30 \times 30 \mathrm{M}$ \\
\hline 2 & DEM (topography and slope) & Glovis.usgs.gov \& own process & $30 \times 30 \mathrm{M}$ \\
\hline 3 & Land use land cover (summer \& winter) & Glovis.usgs.gov \& own process & $30 \times 30 \mathrm{M}$ \\
\hline 4 & Temperature (summer \& winter) & NMA \& own-processing & $30 \times 30 \mathrm{M}$ \\
\hline 5 & Precipitation (summer \& winter) & NMA \& own-processing & $30 \times 30 \mathrm{M}$ \\
\hline 6 & PET (summer \& winter) & NMA \& own-processing & $30 \times 30 \mathrm{M}$ \\
\hline 7 & Wind speed (summer \& winter) & NMA \& own-processing & $30 \times 30 \mathrm{M}$ \\
\hline 8 & Groundwater depth (summer \& winter) & Regional water resources & $30 \times 30 \mathrm{M}$ \\
\hline 9 & Soil parameter lookup table & WetSpass user guide \& literature review & \\
\hline 10 & Runoff coefficient lookup table & WetSpass user guide \& literature review & \\
\hline 11 & $\begin{array}{l}\text { Land use parameters (summer \& winter) lookup } \\
\text { table }\end{array}$ & WetSpass user guide \& literature review & \\
\hline
\end{tabular}
method is that it is fast and easy to implement for a specific

Table 1 Input parameters and sources for WetSpass model 
purpose with few and scattered measured data, each value estimated in an IDW interpolation is a weighted average of the surrounding sample points. Weights are computed by taking the inverse of the distance from an observer's location to the location of the point being estimated. Long-term hydro-meteorological data of the study area was prepared as follows:

Using the above long-term annual average hydro-meteorological data of the nearby principal stations, grid maps of Birki watershed was prepared using the IDW interpolation method in ArcGIS environment. And also the required physical data should have grid file format to read by the model for effective simulation, so, the inputs were prepared using Erdas imagine and ArcGIS environment. The parameters were mentioned in Tables 2, 3.

\section{Parameter tables preparation/lookup tables}

Look up tables are also important for running the WetSpass model, so that, four parameter tables were prepared, they are summer and winter land use land cover, soil texture and runoff coefficient parameters in DBF (database file) format. Basically, the model user guide and some other literature reviews were used to adjust and develop the parameter values to the watershed characteristics. In this section, excel (xls) file to dbf file format converter software was used to prepare the lookup tables and these parameter tables are mentioned in (Tables 4, 5, 6).

\section{Materials and softwares used}

The materials and software's used in the entire research work were discussed as follows (Table 7).

The overall research methodology framework adopted for estimation of groundwater recharge using GIS-based WetSpass model for Birki watershed was mentioned as illustrated in (Fig. 3).

\section{Research results}

\section{Groundwater recharge estimation using WetSpass model}

The WetSpass model was implemented for Birki watershed to estimate long-term seasonal and annual groundwater recharge using 10 years (2006-2015) hydro-meteorological data of surrounding principal stations of Atsebi, Senkata, Wukro and Mekelle stations with the main objective of estimating groundwater recharge for Birki watershed. The results of our simulation using such a long-term biophysical and hydro-meteorological input indicated that groundwater recharge amount varies among seasons. The recharge value 
Table 3 Long-term average seasonal hydro-meteorological data of nearby principal stations (potential evapotranspiration winter \& summer, PET_Win, Sum), mean precipitation (mean_ppt), average temperature and annual average PET

\begin{tabular}{lllllccccc}
\hline Id & Stations & Latitude $\left({ }^{\circ}\right)$ & Longitude $\left(^{\circ}\right)$ & Altitude $(\mathrm{m})$ & PET_Win $(\mathrm{mm})$ & PET_Sum $(\mathrm{mm})$ & Mean_ppt $(\mathrm{mm})$ & $\begin{array}{c}\text { Averg_Temp }\left({ }^{\circ} \mathrm{C}\right) \\
\text { Annual_ } \\
\text { PET }(\mathrm{mm})\end{array}$ \\
\hline 1 & Atsebi & 13.9 & 39.7 & 2659.0 & 943.1 & 507.6 & 600.8 & 14.53 & 1450.7 \\
2 & Mekelle & 13.5 & 39.5 & 2004.0 & 1092.1 & 463.5 & 561.8 & 19.18 \\
3 & Senkata & 14.1 & 39.6 & 2487.0 & 1143.1 & 492.3 & 522.4 & 18.10 \\
4 & Wukro & 13.8 & 39.6 & 2020.0 & 0.0 & 0.0 & 562.3 & 19.66 \\
\hline
\end{tabular}

during the main rainy season in June to September ranges from 0 to $41.09 \mathrm{~mm} /$ year with a mean value of $24.1 \mathrm{~mm} /$ year (Fig. 4a), while the recharge during long dry season ranges from 0 to $1.53 \mathrm{~mm} /$ year with mean value of $0.82 \mathrm{~mm} /$ year (Fig. 4b), and mean annual groundwater recharge ranges from 0 to $42.6 \mathrm{~mm} /$ year with mean value of $24.9 \mathrm{~mm} /$ year, which accounts $7.4 \%$ of the total long-term mean annual precipitation $573 \mathrm{~mm}$ on the entire watershed as shown in (Fig. 4c).

According to the mean annual groundwater recharge values simulated by the model and as illustrated in (Fig. 4c) there are high groundwater recharge values in northwestern parts of the Birki watershed but the lowest groundwater recharge was observed in the southeastern escarpments of the watershed. This variation is due to the biophysical and climatic variations of the watershed and to say some relationships, sandy soils have high groundwater rechargeability than silt and clay soil textures in combination with shrubland use land cover classes but water bodies have the lowest groundwater recharge in the watershed. Combination between the biophysical components and the groundwater recharge values simulated shows that, areas which have gentle slope type, lowest elevation value, with shrubland class and sandy textural classes have high groundwater recharge values whereas hilly slope areas, mountainous areas with bare land class and clay soil textural classes have lowest groundwater recharge in the watershed. This difference depends on the climatic, geological, biophysical and topographic characteristics of the watershed.

\section{Groundwater recharge potential of Birki watershed}

Understanding groundwater potential of a given watershed was important for wise utilization and proper management of the water resource and for developmental water resources programs such as for designing hand dung wells and springs. Based on the yearly groundwater recharge simulated by WetSpass model, Birki watershed has three (high, medium and low) levels of groundwater recharge potential. This groundwater recharge potential was developed based on natural break classification method in ArcGIS environment.
There is high groundwater recharge potential in the northwestern of the watershed with $33 \%$ of the total area coverage of the watershed and medium recharge potential was found around the central and northeastern parts (Fig. 5). In other words, the southeastern, as well as some parts of central, have low groundwater potential. The detail areal coverage of the recharge potential was depicted in (Fig. 6). Based on the groundwater recharge potentiality classification, as a result, the watershed has three classes, these are high (33\%), medium (38.1\%), and low $(29.2 \%)$ groundwater potentiality classes in the entire Birki watershed.

\section{Groundwater safe yield for Birki watershed}

Groundwater used to support crop growth by irrigation can be assessed by means of a safe yield map, which indicates how much groundwater can be abstracted in a sustainable way without depleting the groundwater resources. Safe yield is usually expressed as a percentage of the groundwater recharge. Several authors suggested different percentages, from the least conservative $100 \%$ to a reasonably conservative 10\% (Gebreyohannes et al. 2013). Sustainable yield must be considerably less than the groundwater recharge to sustain both the quantity and quality of streams, springs, wetlands and groundwater-dependent ecosystems (Sophocleous 2000). Hence, in this study, a reasonably conservative estimate of the sustainable yield of $25 \%$ of the groundwater recharge value was adopted from the following formula, i.e., ()(Gebreyohannes et al. 2013). Where SY is the safe yield groundwater abstraction rate expressed in $\mathrm{m}^{3} / \mathrm{d} / \mathrm{ha}$ and $R$ is the total annual groundwater recharge expressed in $(\mathrm{mm})$. The resulting safe yield map of the Birki watershed is presented in (Fig. 7). The value ranges from 0 to $0.29 \mathrm{~m}^{3} / \mathrm{d} / \mathrm{ha}$, with mean value of $0.17 \mathrm{~m}^{3} / \mathrm{d} / \mathrm{h}$. Annually, $0.17 \mathrm{~m}^{3} / \mathrm{d} / \mathrm{ha}$ groundwater can be extracted safely from the watershed. The highest groundwater safe yield values were observed in the northwestern parts of the watershed but the lowest values were also found in the southeastern parts of the watershed (own processing). 

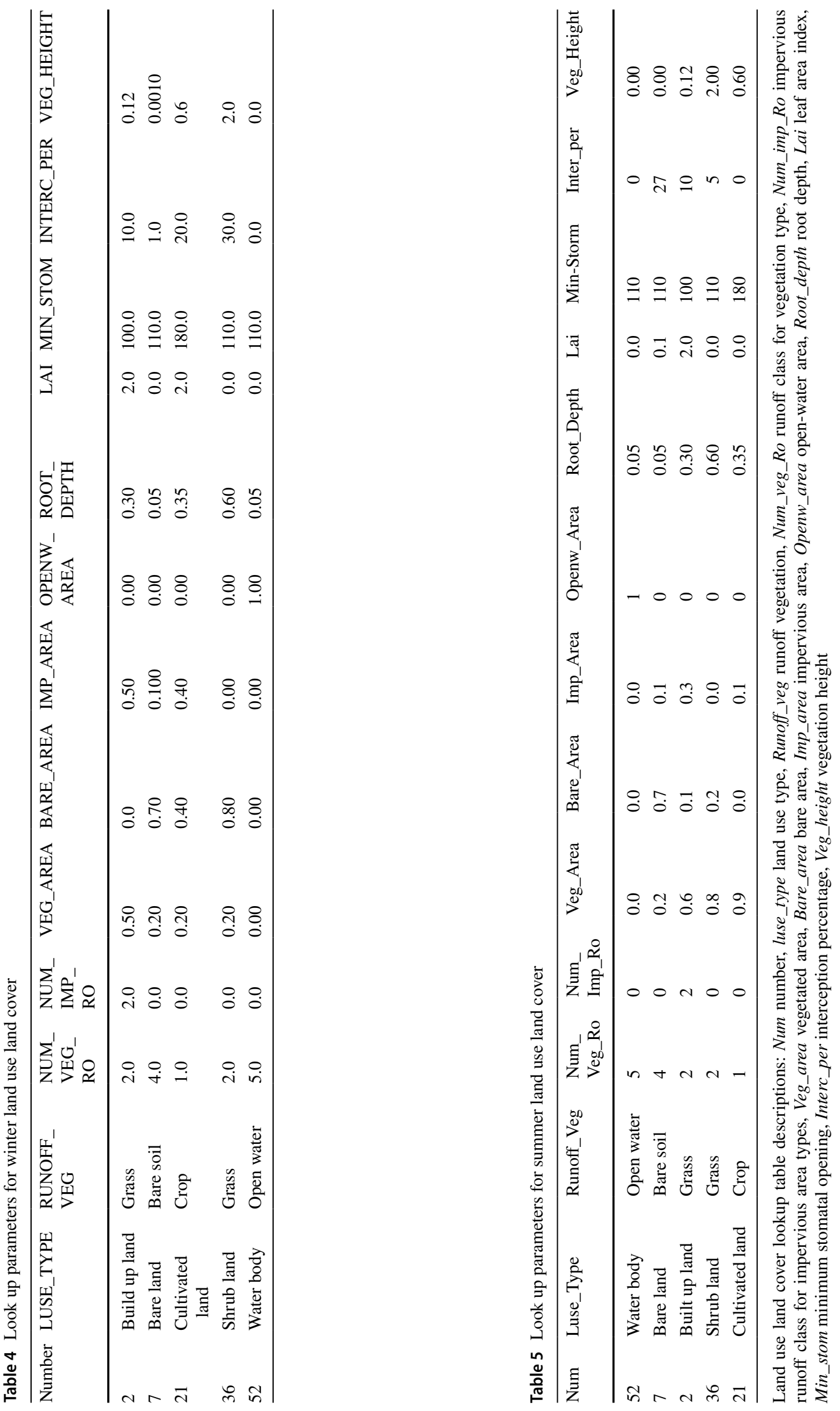
Table 6 Look up parameters for soil texture

\begin{tabular}{lllllllllll}
\hline Num & Soil & Field_Capa & Wilting_PNT & Paw & Resid_WC & A1 & Evapo_dept & Tension_HH & P_Frac_Su & $\begin{array}{l}\text { P_Frac_ } \\
\text { wi }\end{array}$ \\
\hline 6 & Silt & 0.3 & 0.10 & 0.20 & 0.04 & 0.35 & 0.05 & 0.61 & 0.09 & 0.01 \\
12 & Clay & 0.5 & 0.33 & 0.13 & 0.09 & 0.21 & 0.05 & 0.37 & 0.95 \\
1 & Sand & 0.1 & 0.05 & 0.07 & 0.02 & 0.51 & 0.05 & 0.07 & 0.09 & 0.01 \\
\hline
\end{tabular}

Soil textures attribute table descriptions: Num soil type number, Soil soil type, Field Capac field capacity, Wilting PNT wilting point, PAW plant available water content, Resid WC residual water content, $A 1$ calibration parameter dependent on the sand content of the soil, Evapo depth bare soil evaporation depth, Tension HH tension saturated height, P_Frac_Sum fraction of summer precipitation contributing to hortonian runoff, P_Frac_Win fraction of winter precipitation contributing to hortonian runoff

Table 7 Materials and software are used in this research

\begin{tabular}{lll}
\hline No. & Software's and materials & Functions/used for \\
\hline 1 & GPS-Garmin-60 & GCP data, outlet and soil sample data collection \\
2 & ArcGIS software 10.3 & $\begin{array}{c}\text { Grid data preparation, spatial data analysis, interpolation of point data and interpretation of the } \\
\text { simulated results }\end{array}$ \\
3 & Erdas imagine & Layer stacking, LULC classification, and accuracy assessment \\
4 & Arc hydro-tools & Dem hydro-processing, flow direction, flow accumulation, streams network, watershed delineation \\
5 & Arc view 3.2 and WetSpass extensions & Running the WetSpass model \\
6 & Cropwat-8 & Evapotranspiration estimation \\
7 & Google earth & Ground truth collection and feature identification, and to take GCP for inaccessible areas \\
8 & XLS to DBF converter software & To prepare to lookup parameter tables of soil texture, land use land cover, runoff coefficient in \\
& & DBF format \\
9 & Ms-Office-2010 & Reporting and presentation of results \\
\hline
\end{tabular}

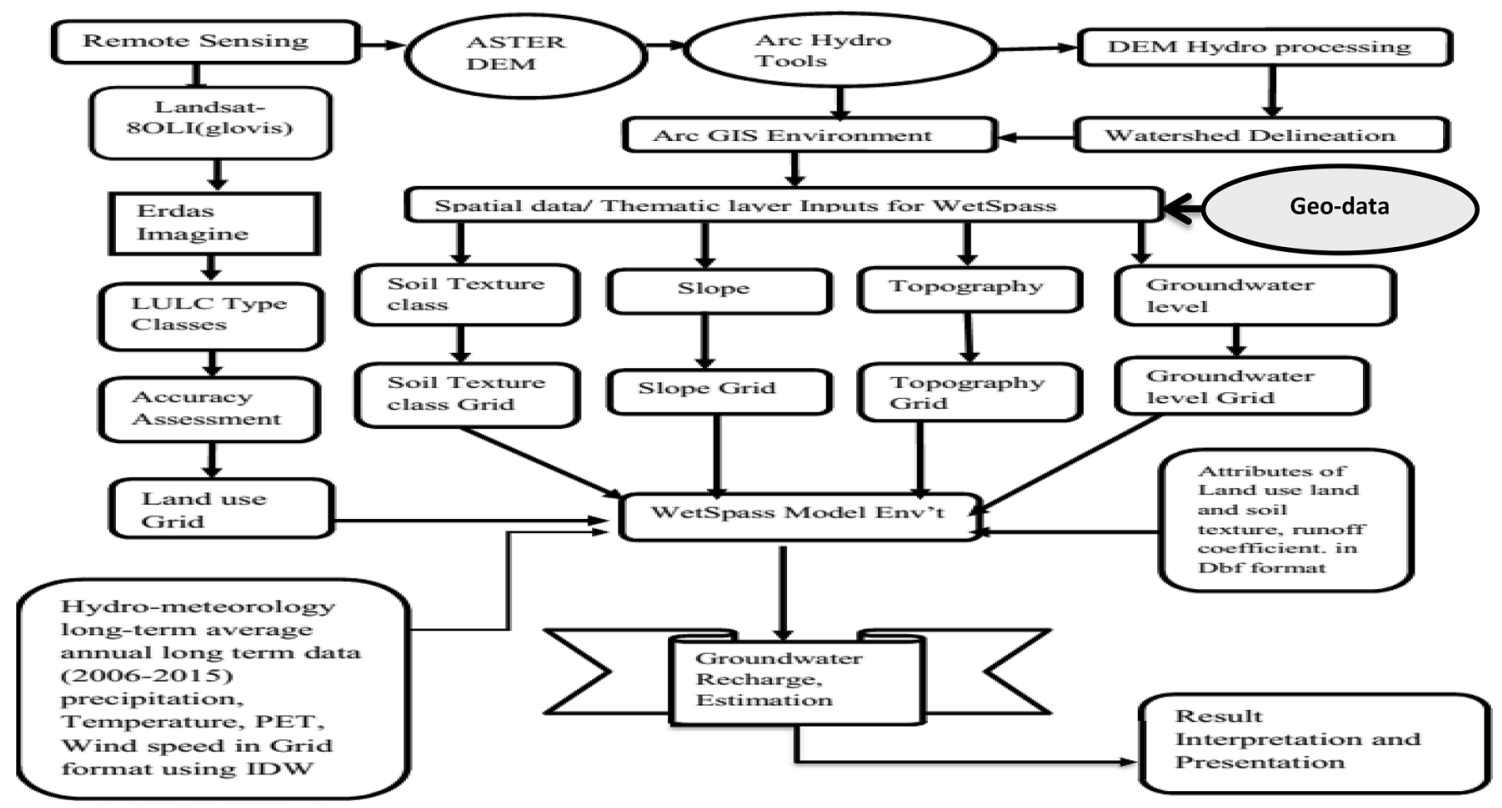

Fig. 3 Research methodology frameworks and different activities and tools used to achieve research objectives 

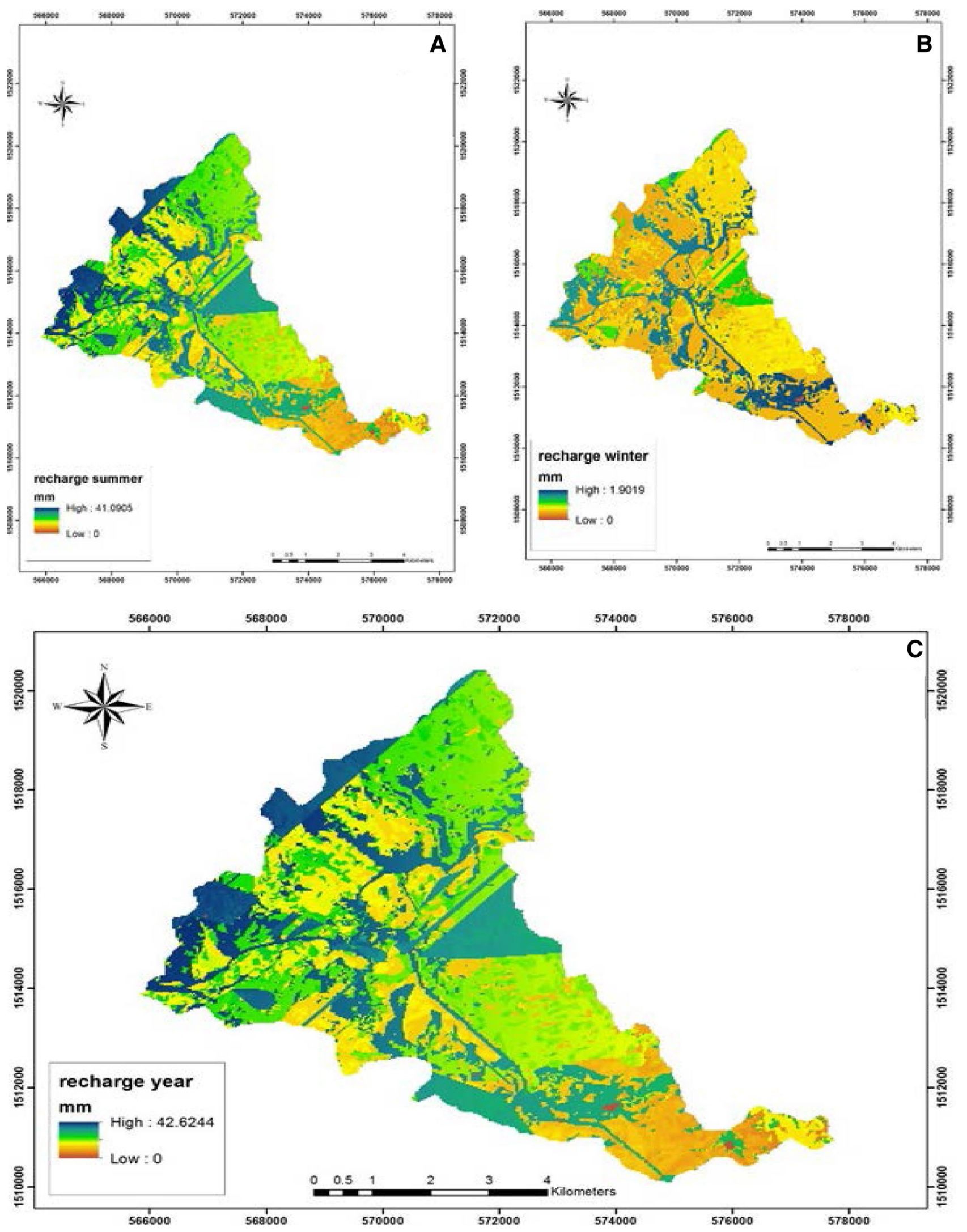

Fig. 4 Shows WetSpass model-based groundwater recharge simulation maps of the Birki watershed during summer season (a), winter season (b) and annual (c) using biophysical and hydro-meteorological characteristics of the watershed 
Fig. 5 Groundwater recharge potentiality map for Birki watershed
Fig. 6 Areal coverage distribution of groundwater recharge potential in percent
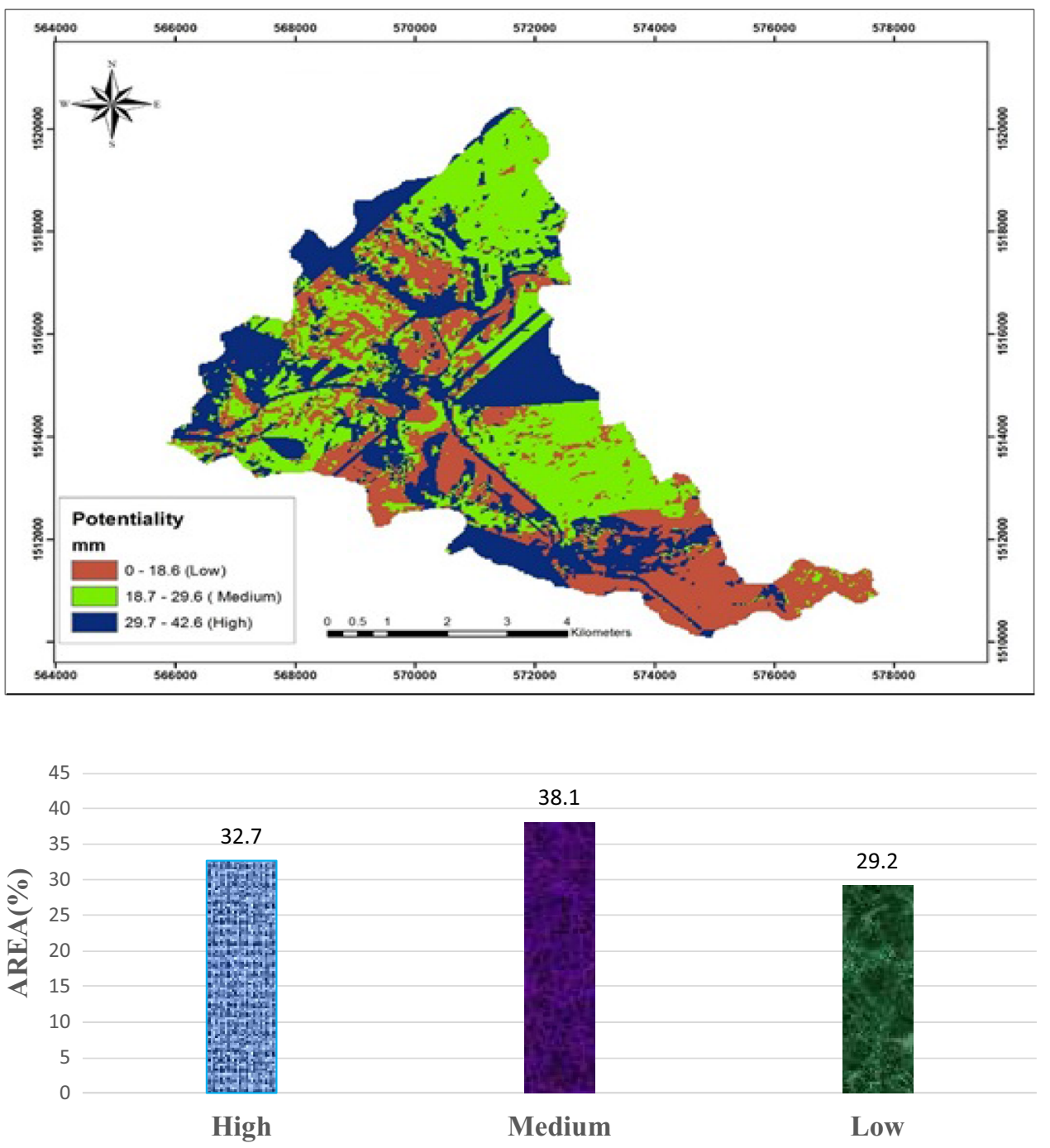

POTENTIALITY LEVEL

\section{Discussions}

This study aimed at estimating long-term seasonal and annual average groundwater recharge value, to map out groundwater recharge potential and groundwater safe yield map estimated by WetSpass model for Birki watershed, located in northern Ethiopia. The result showed that mean annual average groundwater recharge of the Birki watershed was $24.9 \mathrm{~mm} / \mathrm{year}$. The total mean annual rainfall of the watershed $(573 \mathrm{~mm})$ contributes to $7.4 \%$ as recharge to groundwater, $7.1 \%$ of surface runoff and $85.5 \%$ of evapotranspiration. About $96.5 \%$ of the groundwater recharge in the watershed was happened in summer season, i.e., main rainy season and $3.5 \%$ in the winter season (dry season) because of precipitation, temperature, potential evapotranspiration, and soil moisture variations. Moreover, there is high duration, intensity and amount of precipitation distribution, high soil moisture and evapotranspiration in the summer season which accelerated groundwater recharge.

There is high groundwater recharge and evapotranspiration than surface runoff in the watershed because the watershed is a conserved type of watershed and there is high shrub land coverage, in which this facilitates soil infiltration rate and evapotranspiration by reducing surface runoff in the watershed. Recent studies showed that the WetSpass model was implemented in different regions by different authors and their findings showed that their simulation results were acceptable, these simulation results were stated as follows as cited by Zarei et al. (2016).

Abu-Saleem et al. (2010) evaluate the water balance components using WetSpass model for the Hasa basin in Jordan. According to their results, mean annual groundwater recharge and surface runoffs were 0.98 and $23.64 \mathrm{~mm} /$ year, respectively. In other words, about $0.64 \%$ and $15.4 \%$ 
Fig. 7 Groundwater safe yield map of Birki watershed

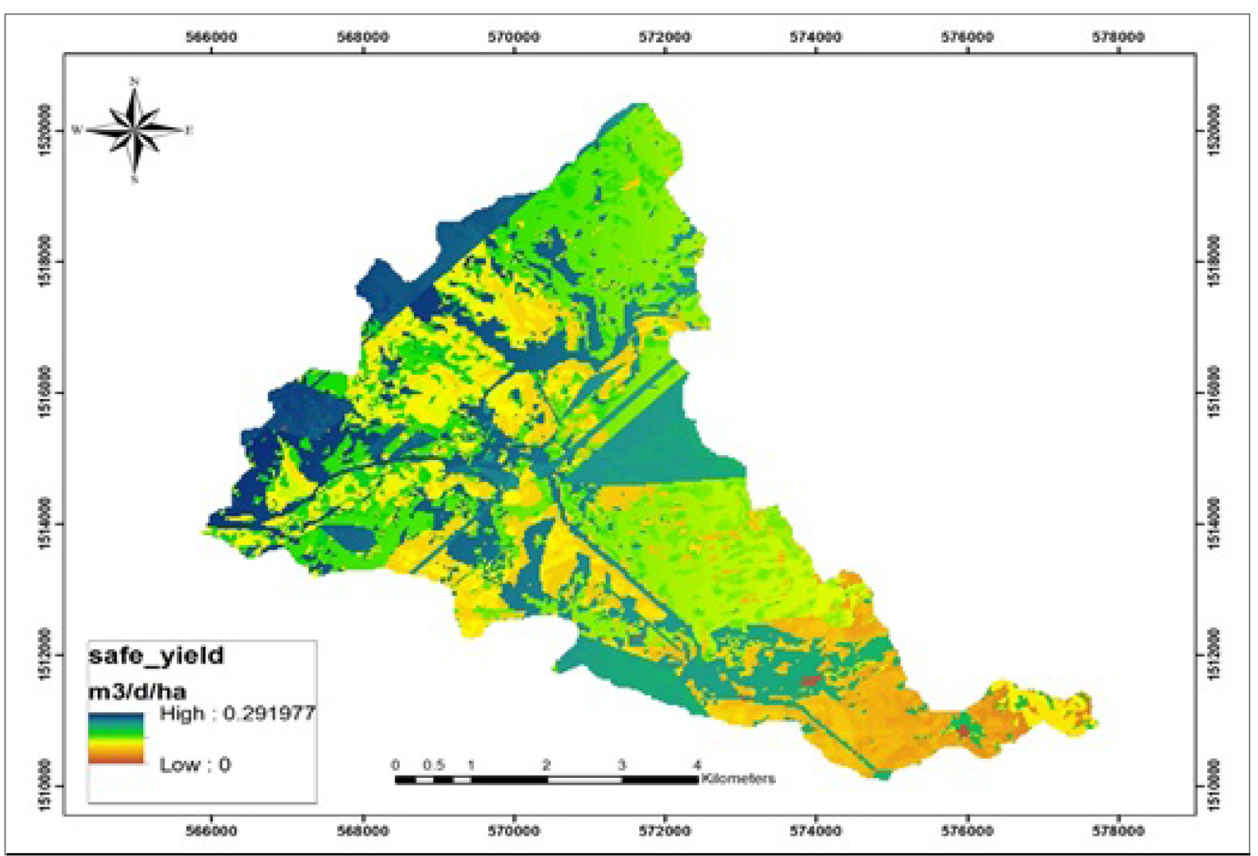

of the annual precipitation convert to groundwater recharge and surface runoff, respectively, and the major part of the precipitation $(83.96 \%)$ is lost as evapotranspiration.

In Northern Ethiopia, Arefaine et al. (2012) simulate the water balance components including groundwater recharge, evapotranspiration and surface runoff using WetSpass model. Results show that the mean annual groundwater recharge, evapotranspiration, and surface runoff were found to be 66,440 and $40 \mathrm{~mm}$, respectively. Therefore, $12 \%$ of the precipitation becomes recharge while evapotranspiration and surface runoff are $81 \%$ and $7 \%$ of the precipitation, respectively, compared to our simulation results surface runoff and evapotranspiration values have some similarity than the recharge value, this may be due to different biophysical factors within the area.

According to the above results, WetSpass model simulates the water balance components in Birki watershed which is $7.4 \%$ as recharge to groundwater, $7.1 \%$ surface runoff, and $85.5 \%$ evapotranspiration have some similarity and difference with the results shown above, this difference can be observed because of variation in hydro-meteorological components, geological formations, climatic variability, physical properties of soils, watershed area, input data and their spatial resolution and conservation practices with a given watershed, such as Birki watershed is a highly conserved watershed that is way the runoff is so small. The groundwater recharge potential was highest in the northwestern parts of the watershed with characteristics of the flat slope, sandy soil, and dominated by shrubland classes and there is low groundwater recharge potential in the southeastern part which has clay soil type, hilly slope and covered by bare land. Understanding the groundwater recharge potential areas of a given watershed is important for designing and developments of hand dung wells as sources of potable water used for different domestic and agricultural activities, based on the groundwater recharge map of the watershed, the potential map was created using natural break classification method into three levels, high, medium and low recharge values. As a result, there is high groundwater potential in the northwestern part but low recharge potentials in the southeastern escarpment of the watershed.

\section{Conclusions}

Water resource is a crucial element of life, so as to maximize its use proper planning, management, and wise utilization is crucial in the twenty-first century. To do so, the development and application of GIS and remote-sensing techniques make the assessment and modeling of water resources easy and effective for such a purpose. The WetSpass model which is a simulation model for groundwater recharge is based on biophysical and hydro-meteorological properties and it is important to estimate long-term annual average groundwater recharge in seasonal and annual basis for wise utilization, proper management and future planning of water resources.

The long-term annual and seasonal groundwater recharge for Birki watershed is $42.6 \mathrm{~mm} /$ year, summer is (41.09 $\mathrm{mm})$, winter is $(0.82 \mathrm{~mm})$ and about $96.5 \%$ of the recharge happened during the summer season and remaining $3.5 \%$ in the winter season. This differences in recharge value are attributed to differences in rainfall amount that leads to the 
differences in the biophysical properties of the catchment and mean annual precipitation $(573 \mathrm{~mm})$ contribute to $7.4 \%$ as groundwater recharge, $7.1 \%$ of surface runoff and the remaining $85.5 \%$ is lost as evapotranspiration in the Birki watershed.

There are high groundwater recharge value and evapotranspiration with low runoff in the watershed, because the watershed is the conserved type with high coverage of shrublands, in which this facilitates infiltration rate and evapotranspiration, but decreases runoff production. There is high groundwater recharge potential in the northwestern parts of the watershed and low groundwater recharge potential in the southeastern escarpments of the watershed.

Groundwater safe yield ranges from 0 to $0.29 \mathrm{~m}^{3} / \mathrm{d} / \mathrm{ha}$, northwestern parts have high values of groundwater safe yield than the other parts of the watershed and the lowest values are in the southeastern part and annually, in average $0.17 \mathrm{~m}^{3} / \mathrm{d} / \mathrm{ha}$ groundwater can be extracted safely without diminishing the groundwater resources and annually, 1.1205 million $\mathrm{m}^{3}$ water recharging to the groundwater from the total annual precipitation in Birki watershed.

Open Access This article is distributed under the terms of the Creative Commons Attribution 4.0 International License (http://creativeco mmons.org/licenses/by/4.0/), which permits unrestricted use, distribution, and reproduction in any medium, provided you give appropriate credit to the original author(s) and the source, provide a link to the Creative Commons license, and indicate if changes were made.

\section{References}

Abu-Saleem A, Al-Zu`bi Y, Rimawi O, Al-Zu`bi J, Alouran N (2010) Estimation of water balance components in the Hasa basin with GIS based WetSpass model. J Agron 9(3):119-125. https://doi. org/10.3923/ja.2010.119.125

Aish A, Batelaan O, De Smedt F (2010) Distributed recharge estimation for groundwater modeling using WetSpass. Ar J Sci Eng 35(1):155-163

Al Kuisi M, El-Naqa A (2013) GIS-based spatial groundwater recharge estimation in the Jafr Basin, Jordan-application of WetSpass models for arid regions. Rev Mex Cienc Geol 30(1):96-109
Arefayne Shishaye H, Abdi S (2015) Groundwater exploration for water well site locations using geophysical survey methods. J Waste Water Treat Anal 7(1):1-7. https://doi.org/10.4172/21577587.1000226

Batelaan O, De Smedt F (2007) GIS-based recharge estimation by coupling surface-subsurface water balances. J Hydrol 337(3-4):337355. https://doi.org/10.1016/j.jhydrol.2007.02.001

Batelaan O, DeSmedt F (2001) WetSpass: a flexible, GIS-based, distributed recharge methodology for regional groundwater modelling. Impact Hum Act Groundw Dyn 269(269):11-17

Fenta AA, Kifle A, Gebreyohannes T, Hailu G (2014) Spatial analysis of groundwater potential using remote sensing and GISbased multi-criteria evaluation in Raya Valley, northern Ethiopia. Hydrogeol J 23(1):195-206. https://doi.org/10.1007/s1004 0-014-1198-x

Gebreyohannes T, De Smedt F, Walraevens K, Gebresilassie S, Hussien A, Hagos M, ... Gebrehiwot K (2013) Application of a spatially distributed water balance model for assessing surface water and groundwater resources in the Geba basin, Tigray, Ethiopia. J Hydrol 499:110-123. https://doi.org/10.1016/j.jhydr ol.2013.06.026

Karimi P, Bastiaanssen WGM (2015) Spatial evapotranspiration, rainfall, and land use data in water accounting-Part 1: Review of the accuracy Hydrol Earth Syst Sci. https://doi.org/10.5194/ hess-19-507-2015

Melesse AM, Abtew W, Setegn SG (2013) Nile River basin: ecohydrological challenges, climate change, and hydropolitics. Springer, New York, pp 1-718. https://doi.org/10.1007/978-3-319-02720-3

Shanableh A, Merabtene T (2015) Geomatics for mapping of groundwater potential zones in the northern part of the United Arab Emiratis-Sharjah City. Sens Spatial Inf Sci. https://doi.org/10.5194/ isprsarchives-xl-7-w3-581-2015

Shiklomanov IA (1998) World water resources-a new appraisal and assessment for the 21st century. Report 40:1-7

Sophocleous MA (2000) From safe yield to sustainable development of waterresources - the Kansas experience. J Hydrol 235:27-43

Sykes JF (2006) The impact of climate change on groundwater 28.1. Water Resour 28:1-42

World Bank (2006) Ethiopia managing water resources to maximize sustainable growth. Hydrol Earth Syst Sci Dis 4(36000):119. https ://doi.org/10.5194/hessd-4-4265-2007

Zarei M, Ghazavi R, Vli A, Abdollahi K (2016) Estimating groundwater recharge, evapotranspiration and surface runoff using land-use data: a case study in northeast Iran. Biol Forum 8(2), 196-202

Zomlot Z, Verbeiren B, Huysmans M, Batelaan O (2015) Regional studies spatial distribution of groundwater recharge and base flow. Assessment of controlling factors. J Hydrol 4:349-368 